\title{
Land Consolidation for Agricultural Growth in Vietnam
}

\author{
Nguyen Thi Thu Huong ${ }^{1}$, Pham Nguyen My Linh ${ }^{2}$, Vo Thi Van Khanh ${ }^{1}$, Nguyen Quang Sang ${ }^{1}$, Le Hoang Anh $^{1} \&$ \\ Hoang Hai Ninh ${ }^{1}$ \\ ${ }^{1}$ Academy of Finance, Hanoi, Vietnam \\ ${ }^{2}$ Asper School of Business, University of Manitoba, Manitoba, Canada \\ Correspondence: Nguyen Thi Thu Huong, Academy of Finance, 58 Le Van Hien Street, Duc Thang Ward, Bac Tu \\ Liem District, Hanoi 10000, Vietnam. Tel: 84-912-670-953. E-mail: nguyenthithuhuong@ hvtc.edu.vn
}

Received: February 18, 2020

Accepted: March 4, 2020

Online Published: March 20, 2020

doi:10.5539/ijef.v12n4p83

URL: https://doi.org/10.5539/ijef.v12n4p83

\begin{abstract}
In order to effectively restructure agriculture, comprehensive solutions are needed, in which the solution of agricultural land consolidation and concentration must be accompanied by strong reform of the conditions of agricultural production such as organizing good inputs and outputs markets, brand building and protection, strengthening agricultural product quality management, improving the competitiveness of the agricultural sector, respecting market rules, so that the markets can regulate the production scale and technology applied with the orientation and support of the Government, etc. In this way, Vietnam's agriculture can enter a new stage of development. This paper analyzes the current situation of agricultural land consolidation in Vietnam. The authors have clarified the results as well as limitations in agricultural land consolidation for Vietnam. The cause of the limitations in agricultural land consolidation for Vietnam in recent years and recommendations to promote land consolidation for agricultural development in Vietnam in the near future.
\end{abstract}

Keywords: Consolidation, land, development, agriculture, Vietnam

\section{Introduction}

Ever since the "Renovation" in 1986, especially after Resolution 10 from the Central Executive Committee of Communist Party of Vietnam in the $6^{\text {th }}$ term in 1988, Vietnamese agriculture had a significant breakthrough. Farmers had been confirmed as an independent economic unit, they have equal rights with other economics parts according to the Law, lands in Vietnam have reached a lot of significant accomplishments, from a country that had a lack of food, now has become the 2 nd biggest country in rice exports.

However, Vietnam agriculture participated in global value chain in the stages of low value-added, simple labor, lack of support from the industry, services, processing, lack of reputation brand, production not following the market, not following the plans, use of poor quality materials and varieties leading to low quality of agricultural products, weak competitiveness in international agricultural market, and state management in the field of agriculture industry also has limitations that lead to devastation of resources and environmental pollution. Originating from the above practice, the authors would like to share their views and recommendations based on scientific and practical solutions on this issue.

\section{Literature Review}

Agricultural production resources include resources, natural environment and biodiversity; in which land is a particularly important factor, both as an object of labor and an irreplaceable labor material in agricultural production (Mundlak, 2000). Inadequacies in land use will greatly affect the agricultural production process, in which fragmentation of land will lead to high costs and waste of land (Blarel, 1992). Inadequacies in land use will greatly affect the agricultural production process, in which fragmentation of land will lead to high costs and waste of land (Blarel, 1992). According to the research by Do Kim Chung (2008), under the pressure of population growth, the development of industry and services together with urbanization reduce land availability. Especially in developing countries, a decrease in cultivated areas becomes an obstacle to the sustainable development of the agricultural sector. Agriculture needs to be mechanized and modernized. However, fragmented land status reduces the efficiency of using machines. Therefore, land consolidation is considered as one of the effective tools for agricultural development (Blarel, 1992). A FAO study (2003) proposed that the concept of land accumulation would support the formation of competitive agricultural production based on overcoming constraints due to 
fragmented land conditions and promoting economies of scale. Land consolidation is one of the factors that facilitate the formation of large commodity production agriculture on the basis of taking advantage of scale by overcoming fragmentation of land, expanding farming areas, avoiding wasting land, ability to apply technology, etc. (Vo, 2017). In addition, land consolidation also contributes to improving soil quality and reducing land degradation (Kim, 2012).

In a market economy, land consolidation is indispensable, Do Kim Chung (2018) stated that the Government's policies and institutions affect greatly on the process of land consolidation; especially land policies such as establishing property rights, land tenure, land tax regulations, etc. Timmer (1991) also argues that government intervention in land policy had a major impact on the development of rural areas. The core issue is that depending on cultural, historical, political and economic factors, governments can choose a different path between equity or efficiency in land use. As is the case in some Asian and African countries, smallholder farming is a common feature. This is primarily related to the family's traditional and cultural magnetism as an inheritance of parents, while most farmers in these countries view land as an important livelihood asset, they still want to keep the land even when farming is at a loss because their main income is still dependent on agriculture. These problems are factors that limit the process of land consolidation (Do, 2000; Nguyen, 2017).

A World Bank study (2016) found that non-agricultural income is higher than agricultural area, the difference between non-agricultural income has greatly affected the land consolidation process. Agriculture is a production sector, although it is important to the society, agricultural prices are often cheap, profits are lower than industry, production is often risky and returns capital slowly, so it is not attractive to invest in agriculture, thereby limiting the process of land accumulation (Do, 2018). The consolidation of productive land depends on the ability of workers to move out of the agricultural sector as well as the real estate market and the land-related legal system (World Bank, 2008). According to Gordon Hanson (2005), migration also plays an important role in promoting land consolidation and reducing inequality in rural areas. The process of urbanization to create better income is a way to reduce poverty. Young and educated people are more likely to migrate and make a difference to farmers who lose their land and do not have the opportunity to participate in off-farm activities. Therefore, the role of education in promoting land consolidation is to create opportunities for career change and income improvement.

Vietnam is a country with an agricultural sector accounting for a high proportion in the country's economic structure. Kim (2012) said that the process of land consolidation is taking place in rural areas of Vietnam. According to this study, there is a difference between the poorest and richest quintile households with access to arable land. Land consolidation in rich households can be explained by better access to financial resources; therefore, land use efficiency is better than poor households. Poor households sometimes have to give up their lands due to their inability to cope with shocks such as natural disasters, epidemics, payment of debts, etc. Therefore, arable land areas of poor households tend to significantly reduce. Landlessness or reduced land area are often associated with poverty (ADB, 2004). Doan (2017) argues that land consolidation in Vietnam now takes place in popular forms such as: Land consolidation in changing the purpose of use from agriculture to construction of industrial parks. Land consolidation forms a closed value chains on a large scale to produce goods with the linkage between farmers and businesses; accumulation within the new type of agricultural cooperative after consolidation, exchange of plots, with active irrigation system. This study proposes a view to accumulating land but not allowing farmers to lose land but to still create commodity products. Completing the land policy, supporting livelihood changes for farmers, supporting enterprises to focus on agricultural land development in the direction of high technology are the solutions that need to be implemented in the coming period to promote effective process of land accumulation, promoting the role of land accumulation, creating potentials for the economy to develop in a modern direction (Vo, 2017).

\section{Method}

The authors mainly used descriptive statistical methods to analyze the reality, opportunities and challenges in the situation of land consolidation in Vietnam agricultural development. The data was collected from Vietnam General Statistics Office over the years.

\section{Situation of Land Consolidation in Vietnam Agricultural Development}

\subsection{Some Forms of Agricultural Land Consolidation in Vietnam}

According to Pham (2017), there are several form of agricultural land consolidation in Vietnam as follows:

- A form of gathering and exchanging plots". In the past, each household unit has 5 to 7 parcels, even up to 10 to 12 parcels. This situation has a negative impact on production. With the help and support from cooperatives, provincial authorities, each unit has voluntarily exchange the plots of lands to each other so as to reduce the 
numbers of fields and at the same time increase the size for the plots. Today, each unit has an average of 2 to 3 plots of lands. "Gathering and exchanging plots" occurred mostly in two periods of time 2008-2010 and 2012-2014, and the majority is rice area at Red River Delta, North Central and South Central Coast. The survey indicated that the average number of fields for each household decreased from 4.72 in 2004 to 2.38 in 2014. However, this method seemed to reach its limit.

- A form of land contribution in agricultural co-operatives. In some provinces, households voluntarily connect to build farming cooperatives. Although involving in farming cooperatives, many households still do their own farming. Cooperatives provide services for each household with watering and fertilizing the ground, plowing, insecticide sprays, harvesting; providing seedlings, fertilizer, high-quality pesticides but lower prices. However, the numbers of cooperatives connecting with business for production, processing and food consumption investing are still restrictive. Through the end of 2015, Vietnam had in total of 10,902 farming cooperatives, mainly focused on Red River Delta area (33.5\%), North Central area (19.7\%), Northeast (16.9\%), Mekong River Delta (11.2\%). Even though this way is supported by many policies and Vietnam Cooperative Alliance enacted in 2012, the growth abilities of cooperatives are still restrictive, especially in capacity management and credit loans approach.

- A form that households buy and receive the transfer of land use rights from other households for production expansion. This method of use happens a lot in Southern area, the majority occurs in Mekong River Delta. By buying the Land use rights, many households could feel secured in long-term investment. Nevertheless, this might experience some barriers. The number of households selling Land Use Rights is small (Especially in Northern area). People sell their lands only under circumstances as they are scared of unstable jobs might not ensure their lives. Land is a property that every household want to give to their children in the future. Therefore, selling and buying Land Use Rights are sometimes certified only through writing letters and uncertain legal basis. Another problem is that some households have properties over the limit for receiving the transfer of land use rights. As a result, each has to have a piece of property in other people's names.

- A form that households rent land of other households for production expansion. This method has become so much more common recently. The benefits are gaining larger scale, bringing the land to the user in the most effective way and at the same time helps with productivity, quality growth and efficiency in agricultural production. The farmers who rent their lands out still keep their Land Use Rights and save the land from turning into fallow land. The method brings effectiveness in both economic and social sides.

- A form that firms associate with households for production. Recently, this method appears and grows a lot. Many households still do farming on their land following the instructions and technical guides from firms; firms invest on providing seedlings, fertilizer, pesticide and buying the final products from the households. Farming households follow advanced technology and produce in the most effective and efficient way without worrying about product consumption. However, this method sometimes has a difficulty which is the land belongs to the households involved in affiliates with firms located between lands that are not involved. As a result, this problem affects traffic system, irrigation, field improvement, product quality guarantee. Besides, there are cases such as households selling products on market when there occurs higher prices compared to the price given by firms.

- A form that firms buy and receive the Land Use Rights from households for production expansion. The method is not widely implemented as many companies do not buy the agricultural land actively from the households for large-scale production. The reason for it is that the purchased price is relatively high which is hard to make profits for only agricultural production. Not only the price that needs to be negotiated, but also about how to negotiate the price with every individual to form large-scale production that are complicated and time-consuming.

- A form that businesses rent households' lands. The firms that have demands in doing business and producing agricultural goods but do not have stable inputs, will sign rental contracts with the households that do not have intentions of producing agricultural goods. With potentials, the firms can apply science and technology, mechanization and be active in inputs source into developing the quality of the products without any concerns. The procedures of land rentals are simple, the farmers keep their Land Use Rights and get to earn profits. Today, there are a lot of companies which rent a thousand of hectares of land for production such as Vincom, TH* True Milk, etc. However, the percentage of firms renting agricultural lands is lower than the percentage of households renting land from other households. That is partly because the rate of firms investing in Vietnam's agriculture is relatively low (accounted for less than 1\% compared to the total firms in the country).

- A form that households contribute land and convert land value into shares of enterprises. In this form, farmers can keep their land use rights and increase their income from dividends on an annual basis according to the shares converted into the value of farmers' land use rights when the enterprises are profitable. If farmers want to work, 
businesses will be given priority to be workers. For its part, the enterprises will have a large enough land fund for professional investment, science - technology and mechanization to improve production efficiency and reduce costs. In the whole country, there are only a few models that are piloting farmers' contributions of land use rights, such as rubber land contribution models in Son La and Lai Chau provinces; land contribution model of farmers in Van Son commune, Trieu Son district (Thanh Hoa province, Vietnam). However, this form has not been effective because it is unclear in contributing capital with land use rights or land use rights value. Farmers are afraid of losing their land use right when businesses lose money (currently, some rubber companies with the participation of many households in the Northwest provinces have not been successful) affecting the lives of households who contribute land to the company as shareholders). Enterprises cannot mortgage land use rights as well as capitalize land use rights to borrow capital to invest in production. At the same time, businesses also face risks in the management and operation of the company due to the many shareholders who are farmers. The applicability of this form is currently very low because it is difficult to have a comprehensive legal framework for capital contribution contracts of enterprises and the coordination of farmers and businesses in corporate management is very limited.

Table 1. Households using agricultural land according to size and area

(Excluding households using land of less than 0.2 hectares)

\begin{tabular}{lccccc}
\hline \multirow{2}{*}{ Units } & \multirow{2}{*}{ Numbers of Units } & \multicolumn{4}{c}{ Land sizes } \\
\cline { 3 - 6 } & & $0.2 \leq$ size $<3$ hectares & $3 \leq$ size $<5$ hectares & $5 \leq$ size $<10$ hectares & $\geq 10$ hectares \\
\hline Red River Delta & $1,323,237$ & $1,322,345$ & 647 & 202 & 43 \\
Northeast & $1,186,664$ & $1,179,804$ & 5.342 & 1,317 & 201 \\
Northwest & 383,007 & 359,692 & 19,632 & 3,548 & 135 \\
North Central & $1,201,763$ & $1,192,675$ & 6,821 & 1,948 & 319 \\
South Central Coast & 613,778 & 601,995 & 8,311 & 2,992 & 480 \\
Highlands & 730,573 & 663,097 & 51,042 & 14,731 & 1,703 \\
South East & 679,911 & 607,160 & 49,183 & 19,583 & 3,985 \\
Mekong Delta & $1,781,091$ & $1,684,383$ & 76,577 & 18,123 & 2,008 \\
Nationwide & $7,900,024$ & $7,611,151$ & 217,555 & 62,444 & 8,874 \\
\hline
\end{tabular}

Source: Tran Kim Chung, Dinh Ngoc Ha, 2017.

For organizations/ businesses that are allocated land, lease agricultural land or concentrate land for large-scale investment, invest in building hi-tech agricultural production areas and practice shows that it is often through the form of capital contribution agreement (signing a land lease contract between enterprises and farmers) and the form of local authorities representing farmers to gather their land and lease it to enterprises. Property registration on land, issuance of certificates of agricultural land use rights to high-tech agricultural areas as well as mortgage mechanisms at credit institutions as a type of asset. These are the forms of land concentration of businesses stemming from needs and practices, while the land law policy does not yet have specific institutions (Tran \& Dinh, 2017).

\subsection{Real Situation of Changing Agricultural Land in Vietnam}

- Agricultural land area plummeted

Vietnam is entering the period of industrialization - modernization and deep international economic integration. However, the paradox is that the more industrialized and urbanized the stronger the agricultural land is, the more people lose land, no more jobs and become poor. Table 2 shows that the total agricultural land area in 2016 decreased by 17,356 ha compared to 2015. In 2017 the total agricultural land area decreased by 16,317 ha compared to 2016. It is worth noting that the land area for agriculture lost completely the fields of the first class, the "sticky rice fields" were taken away to build industrial parks, export processing zones, golf courses or build houses for business. There are long-term licensed industrial zones, but the land is still wasteful (Nguyen, 2008).

Although the rate of agricultural land acquisition in provinces is not high, it is concentrate in some localities with high population density, some communes lose up to $80 \%$ of arable land. Worth mentioning is that most of the planned area belongs to roadside land, fertile land, and land for two rice crops. In particular, there is a reclaimed area that has been abandoned for many years (suspension planning), an area used for golf courses (up to tens of thousands of hectares), with an industrial or entertainment area ... In general, this situation can be called "permanent" concreting agricultural land. It is really a lack of calculation and long-term planning vision, potentially risking economic, political and social insecurity. (Nguyen \& Hoang, 2008). 
Table 2. Changes in Vietnam's agricultural land area in the period of 2014-2017

\begin{tabular}{lcccccc}
\hline & \multicolumn{9}{c}{ Total area } \\
\cline { 2 - 7 } & 2014 & 2015 & 2016 & 2017 & $\begin{array}{c}\text { Comparison between } \\
2016 \text { and 2015 }\end{array}$ & $\begin{array}{c}\text { Comparison between } \\
2017 \text { and } 2016\end{array}$ \\
\hline Total agricultural land & $27,281,040$ & $27,302,262$ & $27,284,906$ & $27,268,589$ & $-17,356$ & $-16,317$ \\
Land for agricultural & $11,505,435$ & $11,530,157$ & $11,526,798$ & $11,508,010$ & $-3,359$ & $-18,788$ \\
production & $4,146,326$ & $4,143,096$ & $4,136,188$ & $4,126,430$ & $-6,908$ & $-9,758$ \\
Rice Land & $14,927,587$ & $14,923,618$ & $14,908,427$ & $14,910,513$ & $-15,191$ & 2,086 \\
Forestry land & 798,537 & 797,759 & 797,295 & 796,053 & -464 & $-1,242$ \\
Aquaculture land & 17,517 & 17,505 & 17,594 & 17,155 & 89 & -439 \\
Salt making soil & 31,964 & 33,223 & 34,792 & 36,858 & 1,569 & 2,066 \\
Others & & & & & \\
\hline
\end{tabular}

Source: Decision No. 2712/QD-BTNMT, Decision No. 455/QD-BTNMT, Decision No. 2311/QD-BTNMT, Decision No. 3873/QD-BTNMT).

\section{- Scale of land use of households above the land limit is not much}

The process of land consolidation is taking place on a small scale: Using fragmented agricultural land according to the scale of smallholder subsistence and self-sufficient agricultural production makes land use less sustainable and less effective. The economic efficiency of land consolidation is clear but there are differences between regions (the Mekong Delta - where commodity economy is more developed than the midland, mountainous and northern delta regions - where small-scale household economy accounts for the majority). Land consolidation has not been closely associated with the reallocation of labor in agriculture and rural areas: farms of less than 3 ha are mostly using family labor, combined with hiring machines to do soil. , harvesting, threshing (the Mekong Delta) or family labor is the main one, combined with seasonal employment (transplanting, harvesting in the North). Some large scale farms of dozens of hectares combine machinery (plows, harvesters and combine-dams) with regular labor (about 10 people) and seasonal workers (Nguyen D. B. \& Nguyen T. T. H., 2017).

\section{- Scale of agricultural land use increases}

As of July 1, 2016, farms used 187 thousand hectares of agricultural, forestry and fishery land, up 35.9 thousand hectares compared to 2011. Of which, there were 60 thousand hectares of land for planting trees. annual; 79.5 thousand hectares of land for perennial crops; 17.6 thousand hectares of forestry land and 29.8 thousand hectares of aquaculture land. On average, 1 farm uses 5.6 ha of agricultural, forestry and fishery production land. Total revenue from agriculture, forestry and fishery production of farms in 2016 reached 93,098 billion VND, an increase of 54,007 billion VND (an increase of 138.2\%) compared to 2011. On average, each farm reached 2,780 million VND, an increase of 828 million dong (up 42.4\%) (General Statistics office of Vietnam, 2016).

\section{- Scale of land concentration in Vietnam is small}

Regarding agricultural production under the model of a large field, according to the General Statistics Office, as of July 1, 2016, the whole country had 2,262 large fields, of which the Red River Delta: 705 fields, accounting for $31.2 \%$ of the fields; Northern Midlands and Mountains: 176 fields, accounting for 7.8\%; North Central and Central Coast: 675 fields, accounting for 29.8\%; Central Highlands: 83 fields, accounting for 3.7\%; Southeast: 43 fields, accounting for 1.9\%; Mekong Delta: 580 fields, accounting for 25.6\%. In general, the scale of land concentration in Vietnam is small, cooperatives and agricultural production enterprises have a large number but the scale of land use is low. Forms of land consolidation, exchange of land, especially the construction of large fields with different models of joint ventures and associates are mainly applied to agricultural land and annual crops (rice, maize, sugarcane). ) and perennial crops, small-scale cattle raising. (Nguyen D. B. \& Nguyen T. T. H., 2017).

\section{- Increased land fragmentation}

Vietnam has a total area of agricultural land (excluding forestry land) of more than 10 million hectares, with about 70 million land parcels and nearly 14 million farm households cultivating and using. Fragmentation and small scale of land are major barriers to Vietnam's agricultural development. The average area of farm households nationwide is $6,603.3 \mathrm{~m}^{2}$, of which the largest area in the Northwest is $15,872.4 \mathrm{~m}^{2} /$ household and the Central Highlands 15,002.8 $\mathrm{m}^{2} /$ household, followed by the Northeast region with $9,275.4 \mathrm{~m}^{2} /$ household, South East $8,359.6 \mathrm{~m}^{2} /$ household, Mekong River Delta 7,994.9 $\mathrm{m}^{2} /$ household and the lowest is the North Delta region with $2,440.5 \mathrm{~m}^{2} /$ household. The average number of land plots of households nationwide is 3.9 plots/ household and the area with the least number of plots/ household is the Southeast (1.6 plots/ household) and Mekong River Delta (1.5 
plots). / household) and the region with the highest number of plots / household is the Northwest (7.1 plots/ household), the Northeast (6.3 plots/ household) (Tran \& Dinh, 2017).

According to GIZ, even in the Mekong Delta, a rice-growing household must have at least 2 hectares to cross the poverty line, it must have at least 3 hectares to be rich and it will be very It is difficult for farmers to break through and rise in the current conditions of fragmented and fragmented land (Ca \& Dung, 2017). The average farming area per Vietnamese agricultural worker is only 0.6 to 0.8 times that of regional countries such as Cambodia, Myanmar and the Philippines (Thao, 2017).

Table 3. Land fragmentation of households

\begin{tabular}{lccc}
\hline All regions & Total area of land $\left(\mathrm{m}^{2}\right)$ & The average number of plots & Average area/ parcel \\
\hline All country & $6,603.3$ & 3.9 & $2,342.5$ \\
Northern Delta & $2,440.5$ & 4.5 & 573.2 \\
Northeast & $9,275.4$ & 6.3 & $1,761.4$ \\
Northwest & $15,872.4$ & 7.1 & $2,355.6$ \\
North Central & $4,912.2$ & 4.8 & $1,102.9$ \\
South Central & $5,339.5$ & 3.4 & $1,592.1$ \\
Highlands & $15,002.8$ & 2.8 & $5,808.8$ \\
South East & $8,359.6$ & 1.6 & $4,025.5$ \\
Mekong Delta & $7,994.9$ & 1.5 & $4,499.1$ \\
\hline
\end{tabular}

Source: Tran Kim Chung, Dinh Ngoc Ha, 2017.

With such a small and fragmented scale of production, farmers can only ensure enough food and carry out simple reproduction; science and technology applicability, intensive farming and increasing the yield of plants and animals in the direction of commodity economy is very limited. Moreover, whatever crops or animals people raise, they are still habitual and spontaneous. For example, coffee, sugarcane, basa fish, tiger shrimp ... if the buy-in price is reasonable enough, people rush to destroy forests to plant coffee, sugarcane, dredge ponds to raise fish and shrimp. But after a few cases, when the market changed, the price dropped and pressed prices, people broke down to return to their old ways of farming. This is a situation of circular restructuring, lack of planning and sustainability, destroying the environment and wasting resources. (Hoang, 2008).

\section{- Land loss due to climate change effects}

Land loss: If global warming causes the sea level rise, many Vietnamese people may lose residential land. A very large portion of agricultural land will also be submerged below sea level. Even though Vietnam is an agricultural country, most Vietnamese farmers have very little cultivated land, especially coastal farmers. Therefore, the loss of a very large proportion of the land fund will put Vietnam facing serious challenges. (Central Institute for Economic Management of Vietnam, 2011)

Soil erosion and washout soil: Climate change disturbs the regime of rain and sun, causes the changes in weather, the amount of rain changes, the amount of nutrients in the soil is lost, ... reducing crop productivity. Vietnam has a total natural land area of 33,121,159 hectares of land, with about 25 million hectares of sloping land, so the risk of land degradation due to erosion and washout is large. The fact shows that in recent years, Vietnamese farmers have invested in a large amount of chemical fertilizers on the soil but they forget to add organic fertilizers to the soil. The continuous use of high doses of chemical fertilizers has made the soil environment acidic, caused the fertile agricultural land to degenerate (Central Institute for Economic Management of Vietnam, 2011).

\section{- Market of agricultural land use rights}

According to the results of the 2014 Household Living Standard Survey, the origin of agricultural land in rural areas is $40 \%$ allocated by the Government, $34 \%$ inherited, only $12 \%$ is purchased directly or auctioned, the remaining is land reclamation or other sources. Specifically, among the purchased agricultural land, $29 \%$ bought before 1994, 41\% bought during the period of $1994-2003$, 30\% bought from 2004 to the present. Meanwhile, the market for leasing land is much lower than the market for transferring agricultural land. In 2014, the percentage of households renting agricultural land was only $10.5 \%$ and the percentage of agricultural land renting was less than $5 \%$, even individual households want to lease their land were mostly limited to the family and relatives. Particularly for forestry land, the rental rate is very small, almost negligible due to limitations in measurement and counts of land disputes (Vy Huong, 2017). 
Currently, since the limit for receiving and transferring of agricultural land is still limited, not exceeding 10 times the assigned limit; domestic enterprises are not allowed to allocate land with collection of agricultural land use fees, but only allow land leasing to invest in agricultural production. Foreign enterprises are not allowed to receive transfer of land use rights. Especially, the property rights to agricultural land are not as secure as other land types (due to lack of ownership). Meanwhile, there is no clear regulation on the role of the Government in supporting enterprises to sublease or receive capital contributions with large-scale agricultural land use rights. In addition, the tax rates and fees related to the transfer of agricultural land are being applied like other real estate with a PIT rate of $2 \%$, which is a bottleneck in land consolidation associated within the market. The aforementioned barriers make the market of the transfer of agricultural land use rights, although developed, have yet to create significant changes, promoting land consolidation and large-scale commodity production (Tien, 2019).

\section{General Review about Land Consolidation for Agricultural Development in Vietnam}

\subsection{Results}

With the efforts of all levels of government, from central to local levels, the process of land consolidation and concentration over the past time has achieved the following positive results:

- Land consolidation helps improve the efficiency in using agricultural land use. In recent years, policies and laws about agricultural land have been increasingly improved, more in line with the socialist-oriented market mechanism, contributing to productivity growth, efficiency in land usage and increasing competitiveness in agricultural products, etc.

- Land consolidation is to modernize the agriculture. A lot of local provinces in Vietnam were and currently performing effectively "Gathering and Exchanging Plots". This is a premise for conducting land consolidation to support agricultural production.

- Through land consolidation, the rights of the farmers are put on top. Land consolidation under any forms all have the same goal which is increasing labor productivity, enhance the efficiency in land use. Therefore, they help increase income for agricultural producers and support society.

- The policies and the laws from the Government about land consolidation help investors feel secured in agricultural land usage

The 2013 Land on Law overcame many limitations of agricultural land use, such as increasing the land use term to 50 years for all types of agricultural land, expanding the land allocation limit to farmer households, allowing the changes in production structure, etc. These have created advantages for agricultural land users to expand production and feel secured in long-term investments.

\subsection{Limitations}

In addition, the process of land consolidation and concentration also raises a number of issues as follows:

- Consolidation causes the loss of livelihoods in some households. Consolidation can be considered as a process which land concentrated from one person to another. Whether for any reason (voluntary or compulsive, rational or unreasonable, plausible or unwarranted), land consolidation and concentration are the causes of loss of a part of the population, this means they lose their traditional livelihood. Livelihoods include the capabilities, assets and activities needed to make a living: land use right is an important asset for rural livelihoods, especially for people who earn their living by only using land. The loss of land-based livelihoods affects not only income but also the psychology and spirit of the people and can cause other social problems ...

- The inequality in rural area in incomes and lands. Land consolidation causes the discrimination in rural area because the lands focus on some few people, leading to the inequality in income. People with populated lands can do business more efficiently and receive higher income than others. This creates negative thoughts in people's minds in rural area.

- Social issues occur in the process of consolidation. When the scale of land expands, a part of the labor force will be taken out of agricultural area. The problem is actually: Where are they going, what to do? And how do social issues arise? That is the problem that needs to be solved in parallel with the consolidation of land for large production. The negative effects of this process indicate that: agglomeration and concentration of land can become socio-political issues and harmonizing the relationship between equity and efficiency is a major challenge.

- Land consolidation has not been given proper tasks in rural area: many farms with area of under three hectares mostly use family labors, mainly combined with renting machines, land preparation, harvesting, or family labor are the main ones, combined with hiring seasonal workers; a few dozen large-scale farms combine equipment (plows and combine harvesters) with regular labor (about 10 people) and seasonal workers. 
- The fields in many areas are still very fragmented (there are nearly 14 million farmers in the country with about 78 million plots), in many places, it is not easy to plan and renovate into convenient areas for production of large commodities, if reconditioning requires large investments.

- The issue of farmers leaving their farms has been occurred since 2005, nowadays, it has become a bigger problem and appeared in many provinces, especially in Red River Delta area and North Central area. Currently, there are different opinions about the positive and negative aspects of this phenomenon. The problem is to consider and realize the true nature of this phenomenon, based on which there are appropriate and effective solutions.

- "Food Security" strategy in Vietnam still has some downsides, inefficiencies in economic, social sides and land usage. Despite the fact that Vietnam exports over seven million tons of rice each year, some provinces are currently lack of food. The land for cultivation of annual crops including paddy land is small, therefore, it creates the low productivity. The farmers are "tied" to the purpose of growing crops because of two reasons: growing crops is a must so as to ensure food source for families, or the local government do not allow using the land with other purposes beside growing crops, even with a small-scale land.

- Land circulation in agriculture commodity development still face some difficulties, not only because of the differences in the costs of inputs and outputs in production, but also the consequences of economic-social and natural elements that cause the harm. Therefore, this creates a bottleneck in circulating and land consolidating processes.

\subsection{Causes of the Restrictions of Land Consolidation in Agricultural Development in Vietnam}

- The causes coming from creating motivations to enhance the land consolidation process

- The country is small with crowded populations, agricultural populations increase rapidly, the abilities of attracting laborers in urban industrial are still weak.

- Opportunity cost in land is relatively low. Small households do not have enough financial requirements, technical and managing skills, information and social relationships for consolidating lands. Thus, agricultural area is not appealing enough for investors due to the low and unstable interest rate.

- The planning is not serious enough to change the purpose of the agricultural land use.

- Cooperative economics has not been developing. Although this method is widely supported by many policies and the Law of Co-operatives in 2012, the possibilities to grow of co-operatives are still restricted, especially in administrative abilities and financial approaches.

- The causes related to Law on Land

- The restrictions in land and the period of time of land usage. To some households, each individual might have questions about restrictions to 10 times usage in Land Use Rights for cultivation, breeding and aquaculture (Article 130, 2013 Law on Land). In Southeast region and Mekong River Delta, the restrictions for one household or individual approximately equal to and below 30 hectares and 200 hectares for each type of land. Households and individuals cannot accept the transfer of Land Use Rights if they do not participate in agricultural production or to agricultural land in the protection forest, the people are required to live there in order to earn the transfer (Clauses 3 \& 4 - Article 191, of the 2013 Law on Land). The conversion of rice land use is only done in the same commune, ward and town.

- The way of changing from land for crop-raising to land for aquaculture and breeding is currently facing some challenges. Solutions to fallow land reduction are not effective, as a result, the trend of keeping land for assurance occurs and the use of land is less efficient.

- The value of transferring the Land Use Rights in agriculture is relatively high, the interest rate in agricultural production is low and has some risks and the support policies for the transfer and Land Use Rights rentals are not strong enough. Therefore, the agricultural land market does not bring back effective results.

- The causes related to perceptions and ideas

- With the thought of agriculture is the only subsistence of farmers, many people still keep in their minds of keeping agricultural land for themselves. In reality, rural laborers, who get out of agriculture field, mostly will choose unofficial labor market with high and hidden risks. It is reasonable for those ones to keep their farmlands.

- The worried mentality about the differences in society with land consolidation.

- Many people believe land dispersion could help reduce the risks (food security in crisis), diversification in production, make the best use of labors and increase the liquidity of land. 


\subsection{Recommendations for Enhancing Land Consolidation for Agricultural Development in Vietnam}

- The resolution team is in charge of completing Government policies and laws on land consolidation for agricultural growth in Vietnam

- Law on Land adjustments. Although the 2013 Land on Law was officially applied from July 1, 2014, there were many articles that help enhancing land consolidation, especially are the time period of transferring the land and the limit of receiving the Land Use Rights. The duration of land allocation is 50 years and the limit of receiving land use right is 10 times of the term for agricultural land. However, the land limit remains unchanged at 3 hectares, which is still an obstacle to the process of land consolidation (Land on Law, 2013). To remove this obstacle, additional amendments to the deadline are required. It is possible to calculate the land limit only for the first time of land allocation, but the land use right transfer does not include the land limit. The next step is to loosen the deadline, even to remove the deadline. The limit of receiving land use right transfer also needs to be raised and gradually removed towards no limit.

- Completing the system, financial policies and credits in agriculture. The tax on agricultural land needs to be adjusted in order to stimulate land consolidation. Law on Tax about using farmland in 1993 decided that if using land over the restricted limit would not only pay tax for the land within the limit but extra taxes for the over limit land are required. By 2010, according to Resolution 55/2010/QH12 about tax exemption and reduction in agricultural land: Tax-free for using agricultural land within the limit of 3 hectares per household and 50\% reduction in tax for using land over the limit, but not over the limit of transferring Land Use Rights days. For agricultural land area exceeding the quota for receiving transfer of agricultural land use right, in addition, the enterprise has to pay $100 \%$ agricultural land use tax. And this Decree is implemented from January 1, 2011 to the end of December 31, 2020. Economically, with these enacted rules, the people will not be encouraged to consolidate agricultural land. The low profits along with the tax on the over-limit in transferring will have a direct impact on profits and investment decisions.

Diversifying the forms and creating credit institutions in rural areas (Government, enterprises, people's credit, etc.) to increase the size of mobilized capital as well as loans through Farmer's Union organizations and groups community organizations, cooperative organizations to expand the scope of activities for the rural credit market, reducing transaction costs for the banking system. Expanding forms of credit guarantee, overcome the situation where farmers and agricultural enterprises are short of capital for production and business, expand the scale of commodity production development.

- Developing the land transfer and lease markets. In order to enhance the consolidation process, the transfer and lease markets should be flexible in procedures. Nowadays, land lease transactions among individuals are completely hand-written, while according to the law, it should be clarified and notarized. According to the Law on Personal income tax No. 04/2007/QH11 and the Law amending and supplementing a number of articles of tax laws No. $71 / 2014 / \mathrm{QH} 13$, the land use right transfer tax is $2 \%$. With the current high price of agricultural land (about 300 to 600 million $\mathrm{VND} / \mathrm{ha}$ ), this tax is quite large. Therefore, the government may exempt or reduce this tax on land transfer transactions to encourage people and businesses to accumulate land, but only apply when the land is used for agricultural purposes (not transferred the change of land use purpose).

- Completing policies for the hosts of the land.

Policies for households and farms. Besides changing some policies in Law on Land, Law on Agricultural Tax or policies of transfer market supports, land rentals; households will be in need of support in equity in land consolidation. First, with the households that have a capacity of consolidating land (financial potentials, labors, management and techniques), the Government needs some programs for loans with supports for interest rate through agricultural banks and agriculture development.

Policies for firms that do land consolidation. Firms can also take part in land consolidating through the methods of land contribution, Government land rentals or households land rentals, etc. However, there are some difficulties in lack of support from the Government. The solution for inefficient agriculture and forestry business is to rent out the land or sell them to other organizations that have demands and possibilities to turn agriculture into business industry. Thus, there needs to have the system and planning when an firms buy land from the farmers as there will be a change in the purpose of using land. The Government could also support businesses by supporting in loans.

- Renovating and completing policies in enhancing research and applications for scientific technology in agriculture

High technology development and application in agriculture must be considered as a key step in transforming the growth model into intensive development, improving quality, efficiency and competitiveness. It is important to 
renovate and improve institutions to promote science and technology research and application, especially high technology in agriculture. In the production chain, from farmers' households to the market all come to responsibilities, benefits, risks sharing among participants; ensure the desired benefits of all. In this requirement, we need to concentrate on developing technology in growing high-quality plants, processing and storing at the best condition; improving cultivation process; ensuring food security; all production forms and improving business.

- Resolutions in advancing the efficiency in land management system

- Cultivation and planning in using land more effectively and efficiently. Cultivating and planning in using land always appear in every conversation discussing about the purposes of cultivation and planning. They create beneficial conditions for effective land using in the future. A group of new policies include experimenting and applying new methods in land consolidation with land division in river area where occurs a complicated cut of economic and social problems, environment. Especially, applying cultivation helps with uniting space helps identify areas are easily affected by climate change and needs appropriate resolutions. In addition, it is necessary to publish the collected and built-in data and maps in the process of land management, environmental management, socio-economic characteristics, urban development, reality about the situation of agricultural, forest, infrastructure and public services development. is the basis for land use planning and planning.

- Land transparency and anti-corruption in land management. The process of ensuring that relevant people have access to land management information is essential to create a good land governance system as this allows land users to perform their rights in participating in the process more effectively. In addition, this approach also helps improve the provision of land management services and the state management of land resources. In this respect, in addition to the development of the Ministry of Natural Resources and Environment's information system on land, water, minerals, marine and environment, the construction of a national spatial data infrastructure (including strategies, management tools and institutions, spatial information, unified information standards, technologies and partnerships) will create greater transparency and stronger participation of all both stakeholders

- Improving the decentralization in land management and building supervising and monitoring system. The current decentralization of land management needs to be improved in order to comply with the following principles: (a) Central is concentrating on developing policies, laws and supervising; (b) division in areas for rights to perform the Government laws in land management.

\section{Conclusion}

Land consolidation has been currently an issue that needs to be discussed even though it has received a lot of supports in policies and positive impacts. However, for agriculture development in Vietnam, especially in the period of international integration, land consolidation is a must.

\section{References}

ADB. (2004). Asian development bank annual report 2004. Manila, ADB.

Blarel et al. (1992). The Economics of Farm Fragmentation: Evidence from Ghana and Rwanda. World Bank Economic Review, 6(2), 233-254. https://doi.org/10.1093/wber/6.2.233

Ca, L., \& Dung. (2017, May 26). Muốn làm giàu phải tích tụ ruộng đất [Want to get rich, must consolidate land]. Retrieved from http://nld.com.vn/kinh-te/muon-lam-giau-phai-tich-tu-ruong-dat-20170526222756232.htm

Central Institute for Economic Management of Vietnam. (2011). Báo cáo: Phát triển đất nuớc truớc nhũng biến động lớn trên thế giới [Report: Developing the country when facing great changes in the world]. Retrieved from http://vnep.ciem.org.vn/Upload/Chuyen\%20de\%20bien\%20dong\%20the\%20gioi\%20Final.pdf

Decision No. 2311/QD-BTNMT of Ministry of Natural resources and environment on approving and announcing results of land area statistics 2016 (2017) (Vn.).

Decision No. 2712/QD-BTNMT of Ministry of Natural resources and environment on approving and announcing results of land area statistics 2014 (2016) (Vn.).

Decision No. 3873/QD-BTNMT of Ministry of Natural resources and environment on approving and announcing results of land area statistics 2017 (2018) (Vn.).

Decision No. 455/QD-BTNMT of Ministry of Natural resources and environment on approving and announcing results of land area statistics 2014 (2017) (Vn.).

Do, K. C. (2000). Thị trường đất đai trong nông nghiệp Việt Nam: Thực trạng và định hướng chính sách [Land market in Vietnam's agriculture: Current situation and policy orientation]. Nghiên cúu kinh tế [Economic 
Research], 260, 21-31

Do, K. C. (2018). Tích tụ và tập trung đất đai: Cơ sở lý luận và thực tiễn cho phát triển nông nghiệp hàng hóa ở Việt Nam [Land consolidation and concentration: Theoretical and practical basis for the development of commodity agriculture in Vietnam]. Tạp chí Khoa học nông nghiẹp Việt Nam [Journal of Vietnam's Industrial Science], 16(4), 412-424.

Doan, T. T. (2017). Cần tích tụ nhưng không để nông dân mất đất mà vẫn tạo ra sản phẩm hàng hóa [Land consolidation is needed but prevent farmers to lose land and still create commodity products, Tap chi Khoa học và công nghệ Nghệ An [Journal of Nghe An province's Science and technology], 7.

General Statistics Office of Vietnam. (2016). Báo cáo so bộ Kết quả Tổng điều tra nông thôn, nông nghiệp và thủy sản năm 2016 [Report on preliminary results of rural area, agriculture and fishery in Vietnam in 2016]. Hanoi, Nhà xuất bản thống kê [Statistical publisher].

Gordon, H. (2005). International migration, self-selection, and the distribution of wages: Evidence from Mexico and the United States. Journal of Political Economy, 113(2), 239-281. https://doi.org/10.1086/427464

Hoang, X. N. (2009, Jun 27). Đột phá chính sách nông nghiệp, nông thôn và nông dân trong giai đoạn hinej nay [Breakthrough of agricultural, rural and farmer-related policies in this period]. Retrieved from https://isponre.gov.vn/home/dien-dan/157-dot-pha-chinh-sach-nong-nghiep-nong-thon-va-nong-dan-trong-g iai-doan-hien-nay

Kim, V. C. (2012). Tích tu tập trung và hiệu quả sủ dụng đất nông nghiệp tại Việt Nam [Land consolidation and use efficiency of agricultural land in Vietnam] (Master thesis). College of Natural sciences (Hanoi National university), Hanoi, Vietnam.

Law No. 04/2007/QH12 of Parliament on Personal income tax (2007) (Vn.)

Law No. 45/2013/QH13 of Parliament on Land (2013) (Vn.).

Law No. 71/2014/QH13 of Parliament on amending and supplementing a number of articles of tax laws (2014) (Vn.)

Mundlak. (2000). Agriculture and Economic Growth: Theory and Measurement (1st ed.). Massachusetts, Harvard University Press.

Nguyen, C. M., \& Hoang, X. N. (2008). Bốn huoóng đột phá chính sách nông nghiệp, nông thôn và nông dân trong giai đoạn hiện nay [Four major breakthroughs in Vietnam's policy of agriculture, rural areas and farmers]. Retrieved

from http://www.hids.hochiminhcity.gov.vn/c/document_library/get_file?uuid=20a3f062-ead4-47f1-891c-4d164 80066e 3 \&groupId $=13025$

Nguyen, D. B., \& Nguyen, T. T. H. (2017, August 16). Một số vấn đề về tích tụ, tập trung đất đai trong phát triển nông nghiệp và nông thôn hiện nay [Several issues related to land consolidation in agricultural and rural development]. Retrieved from https://www.mof.gov.vn/webcenter/portal/vclvcstc/r/m/ncvtd/ncvtd_chitiet?dID=113608\&dDocName=MO FUCM109142\&_adf.ctrl-state=8yu34jhks_4\&_afrLoop=91322636108993190\#!\%40\%40\%3FdID\%3D113 608\%26_afrLoop\%3D91322636108993190\%26dDocName\%3DMOFUCM109142\%26_adf.ctrl-state\%3D of 1 juslm_4

Nguyen, L. D. (2008, November 02). Nhũng vấn đề cấp bách với nông nghiệp nước ta [Urgent problems with Vietnam's agriculture]. Retrieved from http://vietsciences.free.fr/vietnam/xahoi/nhungvandecapbach.htm

Nguyen, V. T. (2017, September 29). Một số vấn đề xung quanh tích tụ, tập trung ruộng đất [Several issues related to land consolidation]. Retrieved from https://baomoi.com/mot-so-van-de-xung-quanh-tich-tu-tap-trung-ruong-dat/c/23406261.epi

Pham, D. (2017, December 06). Tích tụ, tập trung ruộng đất ở Việt Nam trong điều kiện mói: Nhũng vấn đề lý luận và thực tiễn [Land consolidation in Vietnam in a new condition: theoretical and practical issues]. Retrieved

from http://tapchimattran.vn/nghien-cuu/tich-tu-tap-trung-ruong-dat-o-viet-nam-trong-dieu-kien-moi-nhung-vande-ly-luan-va-thuc-tien-10798.html.

Resolution 55/2010/QH12 about tax exemption and reduction in agricultural land (2010) (Vn.).

Thao, N. (2017 July, 22). 6 điểm nhấn lớn trong bức tranh ngành nông nghiệp Việt Nam [Six major highlights in the picture of Vietnam's agriculture]. Retrieved from 
http://cafef.vn/6-diem-nhan-lon-trong-buc-tranh-nganh-nong-nghiep-viet-nam-20170721172622845.chn

Tien, D. (2019, October 24). Phát triển thị trừng quyền sủ dụng đất nông nghiệp còn vấp nhiều rào cản [Developing the market of agricultural land use rights faces many barriers]. Retrieved from http://tapchithue.com.vn/doanh-nghiep-thi-truong/16841-phat-trin-th-trung-quyn-s-dng-dt-nong-nghip-convp-nhiu-rao-cn.html

Timmer. (1991). Agricultural and the state: Growth, Employment, and Poverty in Developing Countries. London, Cornell University Press.

Tran, K. C., \& Dinh, N. H. (2017, September 21). Tích tụ ruộng đất và phát triển kinh tế Việt Nam [Land consolidation and economic development in Vietnam]. Retrieved from https://www.mof.gov.vn/webcenter/portal/vclvcstc/r/m/ncvtd/ncvtd_chitiet?dDocName=MOFUCM114642 $\& d I D=119564 \&$ afrLoop=90657004056311782\#!\%40\%40\%3FdID\%3D119564\%26_afrLoop\%3D906570 04056311782\%26dDocName\%3DMOFUCM114642\%26_adf.ctrl-state\%3Dnv4fnbwuw_4

Vo Khac, S. (2017). Tập trung ruộng đất trong nông nghiệp bước đầu tiên cho sản xuất hàng hóa theo hướng hiện đại [Land consolidation in agriculture - the first step for goods production in the modern direction]. Tap chi Thông tin khoa học và công nghệ Quảng Bình [Journal of Quang Binh Province's Scientific and Technological Information], 6.

Vy, H. (2017, October 11). Phát triển thị truờng quyền sủ dụng đất nông nghiệp [Developing the market of agricultural land use rights]. Retrieved from http://m.daibieunhandan.vn/Chi-tiet?Id=396708\&page=1

World Bank. (2008). Sustainable management of land. International bank for reconstruction and development. Washington, DC, World Bank Publications.

World Bank. (2016). Vietnam Development Report 2016. Washington, DC, World Bank Publications.

\section{Copyrights}

Copyright for this article is retained by the author(s), with first publication rights granted to the journal.

This is an open-access article distributed under the terms and conditions of the Creative Commons Attribution license (http://creativecommons.org/licenses/by/4.0/). 